\title{
DNA DAMAGE IN PERSONS OCCUPATIONALLY EXPOSED TO PHYSICAL AND CHEMICAL GENOTOXIC AGENTS
}

\author{
Pajic J.1, Milovanovic A.2, 3 , Kelkus D.4, Basanets A.5, Milovanovic A. P.S.1, 3 \\ 'Serbian Institute of Occupational Health «Dr Dragomir Karajovic» \\ ${ }^{2}$ Clinical Center of Serbia, Clinic of Physical Medicine and Rehabilitation \\ ${ }^{3}$ Belgrade University School of medicine
}

${ }^{4}$ Academy for applied studies, Belgrade College of Health Studies

${ }^{5}$ Kundiiev Institute of Occupational Health of the National Academy of Medical Sciences of Ukraine, Kyiv

Introduction. Most human genotoxic exposures include interaction of physical and/or chemical genotoxic compounds with genetic material and occur in occupational settings.

This study was conducted in order to evaluate genetic damage in peripheral blood lymphocytes of workers exposed to physical (ionizing radiation) or chemical genotoxic agents (antineoplastic drugs, pesticides) by means of chromosomal aberration and cytochalasine block micronucleus test and to compare their DNA status with unexposed control subjects matched by age and gender.

Materials and research methods. The study population comprised of 127 blood donors: 30 - the control group; 32 - exposed to pesticides, 32 - exposed to antineoplastic drugs and 33 - exposed to radiation. The exposed groups included workers from the agricultural industry, chemotherapy and radiology departments of Serbian hospitals, occupationally exposed to pesticides, antineoplastic drugs or X-rays daily and continually for 5-30 years, respectively. Chromosomal aberrations and micronucleus tests and following cytogenetic slide analyses were performed as described by Fenech (2007), using standard protocols given in the International Atomic Energy Agency (IAEA) technical report (2011).

Results. Statistically significant differences were found between male and female subjects in the control and exposed groups for total number of malignant neoplasm (MN). Smoking status and age were without influence on cytogenetic parameters in all analyzed groups. Analysis of cytogenetic damage parameters showed lower mean values of almost all parameters in the control (unexposed) as compared to the exposed groups, regardless of the exposure agent. A correlation analysis showed significant positive correlations between the duration of the occupational exposure and almost all tested cytogenetic parameters, with the strongest relation between DOE-tMN and DOE-tAC variables.

Conclusion. The results showed influences of gender, occurrence, and duration of exposure on the extent of a cytogenetic damage, but no influence of smoking and age. The obtained data encourage us to consider cytogenetic parameters as valuable markers for preventive medical screening as the extent of cytogenetic damage reflects cumulative exposure events and possible health consequences related to chronic occupational genotoxic exposure.

Key words: chromosomal aberrations, micronuclei, antineoplastic drugs, pesticides, ionizing radiation

\section{Introduction}

Human genotoxic exposures include interaction of physical and/or chemical genotoxic compounds with genetic material (DNA) and are encountered environmentally, occupationally, medicinally, or through lifestyle choices. The exposure to chemical and physical carcinogens in occupational settings is usually more specific and is better defined than environmental exposure for the general population and, in most cases, include the exposure to chemical agents: pesticides, antineoplastic drugs (ANPD), and ionizing radiation (IR) as a physical agent.
Although disparate in nature as to origin, structure and mechanism of action, both chemicals and IR are proven genotoxic agents (Fenech, 2007; IAEA, WHO, 2011). Because of the increased use of such potential mutagens and carcinogens, there is a growing concern regarding occupational risks for the exposed people (Bouraoui et al. 2013; Pajic et al., 2016; Pajic et al., 2018). Moreover, such occupational exposure is typically and durably associated with the use of multiple agents, such that no threshold dose can be clearly identified for their combined genotoxic and carcinogenic effects (Fenech, 2007; Moretti et al., 2015). 
This study was conducted in order to evaluate genetic damage in peripheral blood lymphocytes of workers exposed to genotoxic agents (ANPD, pesticides and IR) by means of chromosomal aberration (CA) and cytochalasine block micronucleus (CBMN) test and compare their DNA status with unexposed control subjects matched by age and gender.

\section{Materials and research methods}

The study population comprised of 127 blood donors: 30 as the control group; 32 exposed to pesticides, 32 exposed to antineoplastic drugs and 33 exposed to radiation. The exposed groups included workers from the agricultural industry, chemotherapy and radiology departments of Serbian hospitals, occupationally exposed to pesticides, antineoplastic drugs or X-rays daily and continually for $5-30$ years, respectively. All the exposed and control subjects lived in the same urban area and were matched for age, gender and smoking habit.

The blood donors were told about the aim and the experimental details of the study and all of them gave informed consent and volunteered to donate blood samples. They were healthy at the time of blood sampling and interviews. Every volunteer completed a standardized questionnaire, designed to obtain relevant details about their current health status, history and lifestyle. It included information about possible confounding factors such as smoking, use of medicinal products, contraception, severe infections or viral diseases during the previous 6 months, recent vaccinations, presence of known indoor/outdoor pollutants, exposure to diagnostic X-rays and previous radio- or chemotherapy. We excluded volunteers who reported alcohol consumption, treatment for acute infections and/or chronic noninfectious diseases, intake of vitamin preparations or intensive sports activities a week before the beginning of the study.
None of the participants reported medicinal treatment during 6 months before blood sampling. Their dietary habits were comparable. None of the participants from the control group reported a history of occupational exposure to known genotoxic chemicals. The routine occupational medical examinations revealed no abnormal finding in any member of each group. The characteristics of the subjects enrolled in this study are summarized in Table 1 .

The participants signed written informed consent forms and the study protocol was reviewed and approved by the Ethical Committee of the Serbian Institute of Occupational Health. Examinations were performed in accordance with the ethical standards of the Helsinki Declaration of 1975 as revised in 2013.

\section{Blood sampling}

Peripheral venous blood samples were taken from each individual by cubital venepunction into lithium heparin vacutainers between 9 and 10 a.m. All blood samples were randomly coded and processed within $2 \mathrm{~h}$ after collection.

\section{Cytogenetic analysis}

Chromosomal aberrations and micronucleus tests and the following cytogenetic slide analyses were performed as described by Fenech (2007) using standard protocols given in he International Atomic Energy Agency (IAEA) technical report (2011).

\section{Statistical analysis}

The frequencies were estimated for several predictor variables, including exposure (control group vs exposed groups), gender (men vs women), smoking habit (smokers vs nonsmokers), age, and duration of occupational exposure (DOE). The control and exposed groups were coded as «control», «P», «ANPD» and «IR», respectively; gender qualifications were coded as «m» for male and «f $\mathrm{f}$. for female; and smoking habits were coded as binary ( 0 or 1 ).

General characteristics of the studied population

\begin{tabular}{|c|c|c|c|c|}
\hline Group & Control & Pesticides & ANPD & IR \\
\hline Gender (male; female) & $19 ; 11$ & $17 ; 15$ & $19 ; 13$ & $14 ; 19$ \\
\hline Age $($ mean \pm SD $)$ & $41.37 \pm 6.05$ & $40.88 \pm 9.07$ & $39.94 \pm 8.76$ & $41.27 \pm 12.87$ \\
\hline $\mathrm{DOE}($ mean $\pm \mathrm{SD})$ & $0.0 \pm 0.0$ & $14.53 \pm 8.09$ & $11.72 \pm 7.80$ & $11.86 \pm 10.32$ \\
\hline Smoking habit (yes; no) & $12 ; 18$ & $16 ; 16$ & $17 ; 15$ & $18 ; 15$ \\
\hline
\end{tabular}


ISSN 2223-6775, Ukrainian Journal of Occupational Health, 2020, 16 (1), 17-22

Age and DOE were used as continuous predictor variables.

The data for CAs and MN were tested for normal dispersion. Parameters $\mathrm{TMN}$ and $\mathrm{tAC}$ fitted a normal distribution curve $(p>.05)$. The frequencies of DIC, $\mathrm{ACE}, \mathrm{CB}$, and $\mathrm{iCB}$ showed significant differences from normal distribution $(\mathrm{p}<.05)$.

A pretest independent sample $t$ test was performed to determine the possible influence of sex and smoking habit on numeric variables. The effects of those nonparametric predictor variables (exposure, gender, and smoking habit) on differences in frequency of CAs and $\mathrm{MN}$ were then tested by an independent sample $t$ test for parameters with normal distribution and the Mann-Whitney U test for parameters with nonparametric distribution.

Correlations between continuous predictor variables (age and DOE) and frequencies of CAs and MN were calculated as Pearson's correlations for variables with normal distribution and Spearman rank correlations for nonparametric variables.
The probability $\mathrm{p}<.05$ was considered statistically significant in each analysis. Uncertainties for all measures of accuracy were expressed as $95 \%$ confidence limits. The analyses were performed using SPSS 17.0 statistics (SPSS Inc.).

\section{Results and discussion}

Two hundred well-spread metaphases and one thousand binuclear lymphocytes per individual were scored for CAs and MNi. The results are presented in Tables 2 and 3 .

First, we examined the influence of proven intrinsic (age, gender) and lifestyle factors (smoking habit) on the extent of cytogenetic damage presented in PBL of our studied population.

Statistically significant differences were found between male and female subjects in the control and exposed groups for the total number of $M N$. The listed parameters had higher values in females. Our results

Table 2

Mean values of cytogenetic parameters in PBL of control subjects and four groups of exposed individuals

\begin{tabular}{|l|c|c|c|c|}
\hline $\begin{array}{l}\text { Parameter } \\
(\mathbf{m e a n} \pm \mathbf{S D})\end{array}$ & Control & Pesticides & ANPD & $\begin{array}{c}\text { Ionizing } \\
\text { radiation }\end{array}$ \\
\hline $\mathrm{tMN}$ & $7.93 \pm 2.85$ & $17.03 \pm 4.37$ & $16.57 \pm 3.09$ & $17.62 \pm 5.09$ \\
\hline $\mathrm{tAC}$ & $2.60 \pm 2.46$ & $12.84 \pm 5.85$ & $10.32 \pm 4.56$ & $10.10 \pm 4.40$ \\
\hline $\mathrm{DIC}$ & $\mathbf{0 . 0} \pm \mathbf{0 . 0}$ & $0.02 \pm 0.0$ & $0.03 \pm 0.0$ & $0.09 \pm 0.0$ \\
\hline $\mathrm{ACE}$ & $0.33 \pm 0.55$ & $1.16 \pm 0.02$ & $1.3 \pm 1.12$ & $0.2 \pm 0.42$ \\
\hline $\mathrm{CB}$ & $0.20 \pm 0.41$ & $2.59 \pm 0.13$ & $2.25 \pm 0.98$ & $0.21 \pm 0.48$ \\
\hline $\mathrm{iCB}$ & $0.13 \pm 0.34$ & $2.18 \pm 0.96$ & $1.25 \pm 1.91$ & $0.36 \pm 0.65$ \\
\hline
\end{tabular}

Note. $t M N$ - total number of micronuclei; tAC - total number of cells with aberrations; DIC - number of dicentric chromosomes; $A C E$ - number of acentric fragments; $C B$ - number of chromatid breaks; $i C B$ - number isochromatid breaks.

Tahle 3

Correlation analysis

\begin{tabular}{|c|c|c|c|c|c|}
\hline & & & \multirow[b]{2}{*}{ iCB } \\
\hline & & tMN & tAC & CB & \\
\hline \multirow{2}{*}{ DOE } & Pearson Correlation & $.544^{*}$ & $.591^{*}$ & $.466 * *$ & $.418 * *$ \\
\hline & Sig. (2-tailed) & .000 & .000 & .000 & .000 \\
\hline \multirow{2}{*}{$\mathrm{tMN}$} & Pearson Correlation & 1 & $.528^{*}$ & $.465^{*}$ & $.407 *$ \\
\hline & Sig. (2-tailed) & & .000 & .000 & .000 \\
\hline \multirow{2}{*}{$\mathrm{tAC}$} & Pearson Correlation & $.528^{*}$ & 1 & $.686^{*}$ & $.687^{* *}$ \\
\hline & Sig. (2-tailed) & .000 & & .000 & .000 \\
\hline \multirow{2}{*}{$\mathrm{CB}$} & Pearson Correlation & $.465^{*}$ & $.686^{*}$ & 1 & $.475^{*}$ \\
\hline & Sig. (2-tailed) & .000 & .000 & & .000 \\
\hline \multirow{2}{*}{$\mathrm{iCB}$} & Pearson Correlation & $.407^{*}$ & $.687^{*}$ & $.475^{* *}$ & 1 \\
\hline & Sig. (2-tailed) & .000 & .000 & .000 & \\
\hline
\end{tabular}

Note. ${ }^{*} p<0.05 ;{ }^{* *} p<0.01$. 
were consistent with the previous studies (Battershill et al., 2008; Coşkun et al., 2013; Fenech 2011; Norppa et al., 2003). The increase in MN frequency in females can be attributed to a greater tendency of $\mathrm{X}$ chromosome to be lost as an MN relative to other chromosomes and to the fact that females have two copies of $\mathrm{X}$ chromosome as compared to males with only one (Norppa et al., 2003).

Smoking status and age were without influence on cytogenetic parameters in all analyzed groups.

Despite the presence of proven carcinogens in cigarette smoke, the published data on the influence of smoking habit on CA and $\mathrm{MN}$ incidence are controversial. Some authors (Fenech, 2007; Rombaldi et al., 2009) showed significant increases in those who smoked more than 30 cigarettes/day, while most laboratories included in the HUMN project (Bonassi et al., 2003) found no significant differences between smokers and non smokers. These data comply with the presented experimental results: our volunteers smoked maximum 20 cigarettes/day, so no significant influence of smoking on micronuclei formation could be expected.

The influence of exposure on cytogenetic status was conducted by pooling together all exposed subjects and comparing them with the control group comprised of unexposed persons. The means for almost all cytogenetic parameters were significantly higher in the PBL of exposed subjects regardless of the agent they were exposed to. The influence of specific agents on cytogenetic damage in PBL was obtained by comparing the control with three groups of the exposed persons. As shown in Table 2, no statistical significance was found in the total number of micronuclei $(\mathrm{tMN})$ in different exposed groups, but persons exposed to pesticides were allocated significantly higher values of CA parameters-tAC and iCB.

\section{References}

1. Battershill J. M. et al. (2008), "Factors affecting the incidence of genotoxicity biomarkers in peripheral blood lymphocytes: impact on design of biomonitoring study. Commentary", Mutagenesis, 23, 423-437. https://doi. org/10.1093/mutage/gen040.

2. Bonassi S. et al. (2003), «Effect of smoking habit on the frequency of micronuclei in human lymphocytes: results from Human MicroNucleus project", Mutation research, 543, 155-166. https://doi.org/10.1016/ S1383-5742(03)00013-9.

3. Bouraoui S., Brahem A., Tabka F. et al. (2011), "Assessment of chromosomal aberrations, micronuclei and proliferation rate index in peripheral lymphocytes
The analysis of cytogenetic damage parameters showed lower mean values of almost all parameters in the control (unexposed) as compared to the exposed groups, regardless of the exposure agent. These findings are related to the literature data (Bouraoui et al., 2011; Pajic et al., 2016; Pajic et al., 2018; Rombaldi et al., 2009).

A correlation analysis (Table 3 ) performed on the exposed subjects only, showed significant positive correlations between the duration of occupational exposure and almost all tested cytogenetic parameters, with the strongest relation between DOE-tMN and DOE-tAC variables. A significant positive correlation is also established between parameters of both applied cytogenetic tests, which is in accordance with our previous studies (Pajic et al. 2016; Pajic et al. 2018 ) as well as with the results of other researchers (Bouraoui et al., 2011; Bouraoui et al., 2013; Eken et al., 2010; Moretti et al., 2015).

This finding suggests that several and continual genotoxic actions are probably more likely to induce genotoxic events than short-term exposures.

\section{Conclusion}

The present study reports the results of the comprehensive screening and evaluation of genotoxicity status of subjects occupationally exposed to various genotoxic agents in Serbia. The data obtained encourage us to consider cytogenetic parameters as valuable markers for preventive medical screening of occupationally exposed groups, since the extent of cytogenetic damage presented in peripheral blood lymphocytes reflects cumulative exposure events and possible health consequences (such as carcinogenesis) related to chronic genotoxic exposure.

from Tunisian nurses handling cytotoxic drugs", Environ Tox Pharm., 250-257. https://doi.org/10.1016/j. etap.2010.11.004.

4. Bouraoui S., Mougou S., Drira A. et al. (2013), "A cytogenetic approach to the effects of low levels of ionizing radiation (IR) on the exposed Tunisian hospital workers", International Journal of Occupational Medicine and Environmental Health, 26 (1), 144-154. https://doi. org/10.2478/s 13382-013-0084-4.

5. Coşkun M., Çayir A., Coşkun M., Tok H. (2013), "Evaluation of background DNA damage in a Turkish population measured by means of the cytokinesis-block micronucleus cytome assay", Mutat Res., 757, 23-27. https://doi.org/10.1016/j.mrgentox.2013.03.010. 
ISSN 2223-6775, Ukrainian Journal of Occupational Health, 2020, 16 (1), 17-22

6. Eken A. et al. (2010), "Cytogenetic analysis of peripheral blood lymphocytes of hospital staff occupationally exposed to low doses of ionizing radiation", Toxicology and industrial health, 26, 273-280. https:// doi.org/10.1177/0748233710365693.

7. Fenech M. (2007), «Cytokinesis-block micronucleus cytome assay. Protocol», Nature Protocols, 2, 1084-104. https://doi.org/10.1038/nprot.2007.77.

8. Fenech M., Bonassi S. (2011), "The effect of age, gender, diet and lifestyle on DNA damage measured using micronucleus frequency in human peripheral blood lymphocytes», Mutagenesis, 26, 43-49. https:// doi.org/10.1093/mutage/geq050.

9. Cytogenetic Dosimetry: Applications in Preparedness for and Response to Radiation Emergencies. (2011), International Atomic Energy Agency, Vienna.

10. Morreti M., Giuseppa Grollino M., Pavanello S. et al. (2015), "Micronuclei and chromosome aberrations in subjects occupationally exposed to antineoplastic drugs: a multicentric approach", Int Arch Occup Environ Health,
88 (5), 683-695. https://doi.org/10.1007/s00420-0140993-y.

11. Norppa H., Falck G. C. (2003), "What do human micronuclei contain?», Mutagen, 18 (3), 221-233. https://doi.org/10.1093/mutage/18.3.221.

12. Pajić J., Jovičić D., Milovanović A. (2017), "Micronuclei as a marker for medical screening of subjects continuously occupationally exposed to low doses of ionizing radiation", Biomarkers, 22 (5), 439-445. https:// doi.org/10.1080/1354750X.2016.1217934.

13. Pajić J., Jovičić D., Milovanović A. PS. (2018), "Cytogenetic surveillance of persons occupationally exposed to genotoxic chemicals», Archives of Environmental \& Occupational Health, 73 (5), 313-321. https:// doi.org/10.1080/19338244.2017.1359144.

14. Rombaldi F., Cassini C., Salvador M. et al. (2009), "Occupational risk assessment of genotoxicity and oxidative stress in workers handling anti-neoplastic drugs during a working week", Mutagen, 24, 143-148. https://doi.org/10.1093/mutage/gen060.

\section{ПейАжік Ажк.', Милованович А. 2, 3, Кекус А.4, Басанешь А.5, Милованович А. П. С., 3 ПОРУШЕННЯ СТРУКТУРИ АНК У ОСІБ, ЯІКІ ЗАЗНААИ ПРОФЕСІЙНОГО ВПАИВУ ФІЗИЧНИХ I XIMІЧНИХ ГЕНОТОКСИЧНИХ АГЕНТIB}

'Сербський інститут професійного зАоров'я імені $\Delta$ октора $\Delta$ рагоміра Караджовіча

${ }^{2}$ Клінічний шентр Сербії, Клініка фізичної медицини і реабіліташії

зУніверситетська школа меАишини, М. Белград

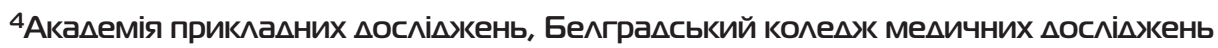

ЭІнститут медицини праші імені Ю. І. КунАієва Нашіональної академії медичних наук України, м. Київ

Bcmyn. Більшість генотоксичних впливівна людину включає взаємодію фізичних і/або хімічних генотоксичних сполук з генетичним матеріалом, що відбувається в професійних умовах.

Мета дослідження - оцінка генетичного ушкодження лімфоцитів периферичної крові працівників, які зазнали впливу фізичних (іонізуюче випромінювання) або хімічних генотоксичних агентів (протипухлинні препарати, пестициди), за допомогою хромосомної аберації та мікроядерного тесту з цитохалазіновими блоками для порівняння статусу їхніх ДНК з неекспонованими контрольними суб'єктами залежно від віку та статі.

Матеріали та методи дослдідження. Досліджувана популяція складалася з 127 донорів крові: 30 - контрольна група; 32 - зазнали впливу пестицидів; 32 - приймали протипухлинні препарати і 33 - зазнали впливу радіації. Групи, які зазнали впливу, включали працівників сільськогосподарського виробництва, пацієнтів відділень хіміотерапії та радіології сербських лікарень, які піддавалися професійного впливу пестицидів, протипухлинних препаратів або рентгенівського опромінення щодня й безперервно протягом 5-30 років. Хромосомні аберації та мікроядерні тести й наступні цитогенетичні слайд-аналізи проводили, як описано Fenech (2007), з використанням стандартних протоколів, наведених у технічному звіті Міжнародного агентства з атомної енергії (МАГАТЕ) (2011). Результати. Статистично значимі відмінності були виявлені між суб'єктами чоловічої та жіночої статі в контрольній і досліджених групах за загальною кількістю злоякісних новоутворень. Статус куріння й вік не впливали на цитогенетичні параметри в усіх аналізованих групах. Аналіз параметрів цитогенетичних порушень показав більш низькі середні значення майже всіх параметрів у контролі (що не зазнали впливу) порівняно з групами, що зазнали впливу, незалежно від агента впливу. Кореляційний аналіз показав значну позитивну кореляцію між тривалістю професійного впливу й майже всіма протестованими цитогенетичними параметрами в разі найбільш сильних зв'язків між змінними DOE-tMN i DOE-tAC.

Висновки. Результати показали вплив статі, частоти та тривалості впливу на ступінь цитогенетичного пошкодження, але не вплив куріння та віку. Отримані дані спонукають нас розглядати цитогенетичні параметри як цінні маркери для профілактичного медичного скринінгу, оскільки ступінь цитогенетичного пошкодження відображає події кумулятивного впливу й можливі наслідки для здоров'я, пов'язані з хронічним професійним генотоксичним впливом.

Ключові слова: хромосомні аберації, мікроядра, протипухлинні препарати, пестициди, іонізуюче випромінювання 


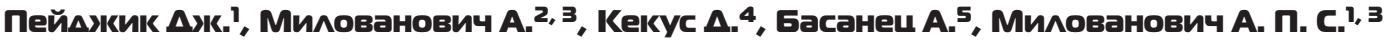 ПОВРЕХКЕНИЯ СТРУКТУРЫ АНК У АЮАЕЙ, ПОАВЕРГАЮШИХСЯ ПРОФЕССИОНАЛЬНОМУ ВОЗАЕЙСТВИЮ ФИЗИЧЕСКИХ И ХИМИЧЕСКИХ ГЕНОТОКСИЧЕСКИХ АГЕНТОВ
}

\author{
'Сербский институт профессионального зАоровья имени $\triangle$ октора $\triangle$ рагомира КараАжовича
}

${ }^{2}$ КАинический шентр Сербии, Клиника физической медицины и реабилиташии

зУниверситетская школа медишины, г. Белград

${ }^{4}$ Акацемия приклацных исследований, Белградский комлеАж меАишинских исследований

БИнститут меАишины труда имени Ю. И. КунАиева Нашиональной академии меАицинских наук Украины, г. Киев

Вступление. Большинство генотоксических воздействий человека включает взаимодействие физических и/или химических генотоксических соединений с генетическим материалом, что может происходить в профессиональных условиях. Цель исследования - оценка генетического повреждения лимфоцитов периферической крови работников, подвергшихся воздействию физических (ионизирующее излучение) или химических генотоксических агентов (противоопухолевые препараты, пестициды), с помощью хромосомной аберрации и микроядерного теста с цитохалазиновыми блоками для сравнения статуса их ДНК с неэкспонированными контрольными субъектами, сопоставимыми по возрасту и полу. Материалы и методы исследования. Исследуемая популяция состояла из 127 доноров крови: 30 - контрольная группа; 32 - подвергшихся воздействию пестицидов; 32 - принимающие противоопухолевые препараты и 33 - подвергшихся воздействию радиации. Группы, подвергшиеся воздействию, включали работников сельскохозяйственного производства, пациентов отделений химиотерапии и радиологии сербских больниц, которые подвергались профессиональному воздействию пестицидов, противоопухолевых препаратов или рентгеновскому облучению ежедневно и непрерывно в течение 5-30 лет. Хромосомные аберрации и микроядерные тесты и последующие цитогенетические слайд-анализы проводили, как описано Fenech (2007), с использованием стандартных протоколов, приведенных в техническом отчете Международного агентства по атомной энергии (МАГАТЭ) (2011).

Результаты. Статистически значимые различия были обнаружены между субъектами мужского и женского пола в контрольной и облученной группах по общему количеству злокачественных новообразований (3Н). Статус курения и возраст не влияли на цитогенетические параметры во всех анализируемых группах. Анализ параметров цитогенетических нарушений показал более низкие средние значения почти всех параметров в контроле (не подвергшихся воздействию) по сравнению с группами, подвергшимися воздействию, независимо от агента воздействия. Корреляционный анализ показал значительную положительную корреляцию между продолжительностью профессионального воздействия и почти всеми протестированными цитогенетическими параметрами, при наиболее сильной связи между переменными DOE-tMN и DOE-tAC.

Заключение. Результаты показали влияние пола, частоты и продолжительности воздействия на степень цитогенетического повреждения, но не влияние курения и возраста. Полученные данные побуждают нас рассматривать цитогенетические параметры как ценные маркеры для профилактического медицинского скрининга, поскольку степень цитогенетического повреждения отражает события кумулятивного воздействия и возможные последствия для здоровья, связанные с хроническим профессиональным генотоксическим воздействием.

Ключевые слова: хромосомные аберрации, микроядра, противоопухолевые препараты, пестициды, ионизирующее излучение

Contributions of the authors:

Pajic J. (ORCID ID 0000-0002-6177-9471) - the author collected data, performed cytogenetic analyses, contributed in statistical analysis and wrote manuscript;

Milovanovic A. (ORCID ID 0000-0003-2138-4915) - the author participated in data collection, contributed in statistical analysis and manuscript writing;

Kekus D. - the author participated in data collection, contributed in statistical analysis and manuscript writing;

Basanets A. (ORCID ID 0000-0001-8236-4251) - the author contributed in statistical analysis and manuscript writing; Milovanovic A. P. S. (ORCID ID 0000-0002-9505-6124) - the author participated in data collection, contributed in statistical analysis, manuscript writing and English language editing.

Information on the research funding source: the research was funded by the National Center of Public Health and Analyses under topic 39 «Health surveillance in health care sector» of National Programme on Safety and Health at Work, 2018-2020.

Надійшла: 30 січня 2020 p.

Прийнята до друку: 26 лютого 2020 р.

Контактна особа: Пейджік Дж., Сербський інститут професійного здоров'я імені Доктора Драгоміра Караджовіча, буд. 29, Деліградська, м. Белград, Сербія. Тел.: 00381649676 384. Електронна пошта: jejapajic@gmail.com 